\title{
Project studies and engaged scholarship
}

Directions towards contextualized and reflexive research on projects

\section{Geraldi, Joana; Söderlund, Jonas}

\section{Published in:}

International Journal of Managing Projects in Business

Link to article, DOI:

10.1108/IJMPB-02-2016-0016

Publication date:

2016

Document Version

Peer reviewed version

Link back to DTU Orbit

Citation (APA):

Geraldi, J., \& Söderlund, J. (2016). Project studies and engaged scholarship: Directions towards contextualized and reflexive research on projects. International Journal of Managing Projects in Business, 9(4), 767-797. https://doi.org/10.1108/IJMPB-02-2016-0016

\section{General rights}

Copyright and moral rights for the publications made accessible in the public portal are retained by the authors and/or other copyright owners and it is a condition of accessing publications that users recognise and abide by the legal requirements associated with these rights.

- Users may download and print one copy of any publication from the public portal for the purpose of private study or research.

- You may not further distribute the material or use it for any profit-making activity or commercial gain

- You may freely distribute the URL identifying the publication in the public portal 


\title{
Project Studies and Engaged Scholarship: Directions towards Contextualized and Reflexive Research on Projects
}

\author{
Joana Geraldi (1) and Jonas Söderlund (2)
}

(1) ProjectLab, DTU Management Engineering, Engineering Systems Division, Denmark

(2) BI Business School, Olso, Norway

This paper has been published in the International Journal of Managing Projects in Business. Cite as:

Geraldi, J. \& Söderlund, J. (2016) Project studies and engaged scholarship: directions towards contextualized and reflexive research on projects. International Journal of Managing Projects in Business, 9(4), 767 - 797 (in the time of writing, the article has been downloaded 81 times in the 20 days it has been made available online).

\section{Abstract}

Purpose: A decade has passed since the 'Rethinking Project Management' Network called for a paradigm shift in project research, and proposed five research directions. This paper reflects on the past decade and purports to rejuvenate these research directions.

Approach: We conceptualise and study 'project studies'. We approach our research as a social process embedded in research communities, and contemporary Zeitgeist. In this regard, the 'Rethinking Project Management' Network acts as a case of researchers and practitioners who took an active role in shaping the research direction of our community.

Findings: Based on Sandberg's interpretive approach to the fit between work and works (in this case research-researcher) and Habermas' three types of human interests: technical, practical and emancipatory, we develop a conceptual framework circumscribing three types of project research, which are used to craft future research directions, in the lines proposed by Winter et al (2006).

Implications: We conclude by proposing a sixth direction on the practice of theorising, and call for engaged and ambidextrous scholars, who's ‘job’ goes beyond the writing of articles and research applications, and includes shaping discourses of project research, nurturing new project scholars, contributing to project practice and carefully considering the legacy of projects and project studies in society.

Originality: This essay positions research as a social process, and the role of researchers as actors shaping research.

Keywords: rethinking project management, sociology of science, scholarship, reflexivity, Habermas, interpretive ontology 


\section{Introduction}

Sociologists of science remind us that research is a social process and a social practice; research and the findings it produces are influenced by who researchers are, their ideologies and convictions, network, research community, and the wider contemporary 'Zeitgeist' (Merton 1973). 'We' are not an exception. Alluding to Dunne's well known "no man is an island" and its later application to project domain "no project is an island" (Engwall 2003), this paper argues that the study of projects is not an island. The observations do not undermine the value of 'science' as such. Instead, the intention is to open the scope for the study of the 'making of science'. In contrast to bibliometric studies looking for links between researchers (e.g. Artto et al. 2009; Pollack \& Adler 2014; Hanisch \& Wald 2012) and the perspective of research as conversations (Huff 1999), we explore the relationship between research and researcher, and how each one of us project scholars plays an active role in conceptualising our research individually, and, in so doing, influencings the direction of our community, and vice-versa.

'We' (or 'our community') refers to the community of scholars studying projects, temporary organizations, project organizing, the management of projects, and project management. This includes the readers and writers of this journal, as well as the community of peers, who usually participate in IRNOP (the International Research Network on Organizing by Projects), EPOC (the Engineering Project Organizations Conference), and/or the project tracks in the general organization and management conferences, such as EURAM (the European Academy of Management) and EGOS (the European Group of Organizational Studies). This community publishes (although not exclusively) and is involved in the editorial of journals dedicated to projects, most notably, the International Journal of Project Management, Project Management Journal and this journal. The community and its object of study receives a variety of names, representing different perspectives on projects (Jacobsson et al. 2015), schools of thought (Söderlund 2011; Bredillet 2010), methodologies (Crawford, Pollack, et al. 2006; Smyth \& Morris 2007), and paradigms (Pollack 2007; Williams 2005; van der Hoorn \& Whitty 2015). Names matter (Pellegrinelli 2011; Geraldi \& Teerikangas 2009), but what connects us matter too. Indeed, together, we form the scholars with a strong interest in and dedication to studying projects. Analogously to organisation studies, we refer to our community as project studies, and ourselves as project scholars. Project studies and scholars will be the object of discussion in this essay.

To illustrate our point, we explore the work of the Rethinking Project Management Network (hereafter the Rethinking Network), - which was summarised in a Special Issue published in 2006 in the International Journal of Project Management. The Rethinking Network presents a widely recognised case of scholars and practitioners taking an active role in shaping the research direction of our community. Funded by the EPSRC (Engineering and Physical Sciences Research Council), a prestigious research council in the UK, the Rethinking Network had the ambition to improve project practice and research. It was formed by academics in close collaboration with practitioners, who discussed the developments of the field. The research has become a milestone in project studies which is demonstrated by, for example, this very Special Issue. It inspired directly and indirectly a large number of research and similar initiatives, in, for example, Denmark (Svejvig 2012).

One of the articles in the special issue, Winter et al (2006), summarised key insights and suggested five themes for rejuvenating project practice and research. These themes were set in the crossroads 
of project scholars and practitioners: (1) theories of the complexity of projects and project management; (2) projects as social processes; (3) value creation as the prime focus; (4) broader conceptualisation of projects, and (5) practitioners as reflective practitioners. As shown in a recent literature review on Rethinking Project Management (Svejvig \& Andersen 2015), these five themes are insightful, but not 'new'. Instead, they captured the Zeitgeist at the time.

Now, ten years later, research, practice and society have changed, in some senses rather fundamentally. For example: the economic crises in 2008, the Arab spring in 2010-11, the occupy movement in 2011-12, the Syrian war and the refugee 'crisis' peaking in 2015. On a more subjective level, we observe, for example, the intensification of worldwide connectivity and wider impact of social media in how we act in society, a stronger yet still remarkably 'silent' discussion on privacy vs. security, and an ever stronger urge to address the causes and consequences of climate change.

In management and organizations, employability is gaining relevance over employment - much of it driven by projects. Fellowship and meaning at work have also gained more attention. The academic landscape has also changed. Impact rather than quantity of publications has become a measurement of research productivity and quality. While pressures for publication in high- ranked journals has intensified, academics are also more critical towards the publish-or-perish approach, and search for alternative outlets of research and influence in society through blogs, social movements, and open science..

Education is also under turmoil. MOOCs (Massive Online Open Courses) can bring Ivy Leaguelevel lectures to any place in the world on customised time, rhythm, and even content. This can potentially reshape higher education, including business and management schools. Indeed, it gets increasingly difficult to justify the price tag on MBAs and open courses if, for example, Stanford (who is leading the way in the Coursera platform) and other top schools offer courses and lectures free of charge or at competitive fees. Developments in education technology enrich learning experience through, e.g. blended learning, gaming and other experimental learning methods. In sum, much happened in the last decade, which re-shapes the contemporary Zeitgeist and points to exciting (and terrifying) trends.

We take this paper as an opportunity to reflect on the last decade.

Our reflection is not an attempt to review publications conducted in project studies in the last decade. Several reviews have been undertaken since 2006, with different focuses. For example, Söderlund (2011) illustrated the pluralism of research in project studies through a comprehensive literature review of over 300 articles across the leading management and organization journals, Pollack and Adler (2014) conducted a quantitative analyses of 94,472 unique records from 1962 to 2012 published in the project management field, Kwak \& Anbari (2009) reviewed publications related to projects outside classic project management publication outlets, and Biedenbach \& Müller (2011) analysed the philosophical stances of project studies following 15 years of IRNOP. Here we do not provide a comprehensive account of all publications specifically related to or triggered by the rethinking project management movement. Such endeavors have been conducted by, for example, Svejvig \& Andersen (2015), and counts with a review of 72 key publications related to rethinking project management. 
Instead, this paper proposes a few directions for future research in project studies. In line with Winter et al.'s motivation back in 2006, the proposed research directions are not meant to be the agenda as such but rather a reflection around ideas that may inform and stimulate current and future research, as well as offer constructive ideas informing the practice of doing research.

Our approach has two anchoring points. First, we anchor our analysis in the five research directions proposed by the Rethinking Network (Winter, Smith, Morris, et al. 2006). Second, inspired by Sandberg (2000)'s interpretative view on the relationship between work and worker (in this case research and researcher) and, by Habermas' three types of human interests, we propose three types of project research. We apply these three types of research to the five research directions proposed by Winter et al (2006). We discuss the rethinking network's message, and cursorily explore the research in the last decade, in response (directly or not) to the call. We then propose directions for future research. We conclude with implications for project studies, by proposing a sixth direction of research, which focuses on the practice of theorising and call for more elaborate reflective and engaged research.

This essay seeks to contribute to our understanding of the history and the current state of the field. We would also like to contribute to our understanding of the role that that Rethinking Network and its publications had for the development of the field. Second, building on the insights from the Network we would also like to point out how we might move forward to an even more reflexive, societal, and emancipatory view on projects - to better understand project management as a social practice, project studies as a social practice, and the role of project management practice and research in society - what we label Type 3 research. Finally, we aim to add a new, relatively unexplored perspective to the debate, by arguing that one of the fundamental contributions of research is the production and reproduction of researchers. Based on this standpoint, we also believe that research as a community must have the capability to produce reflective and engaged scholars that can perform engaged research. This is true in social sciences, and also in project studies.

Our reflections and agenda come with caveats. First, it draws and is limited to the authors' subjective perception of project studies and our contemporary Zeitgeist. We artificially divide the work around decades and types of research, which does not reflect all that has been published in projects studies. Moreover, the essay is not meant to be exhaustive, or reflect the view of most members of the community, but we hope some will be in agreement, and some may find it even inspiring. Some might disagree and our hope is that such disagreements will trigger debate and discussion about the current state of our field and its future trajectories.

\section{Three types of project research}

As mentioned above, we take an interpretative perspective to explore the sociological perspective of project studies. The interpretative perspective presumes that the individual and world are inextricably related through the person's lived experience of the world (Berger \& Luckmann 1966; Husserl 1970; Schütz 1945). Thus, the relationship between work and worker is developed through the lived experience of work, and the meaning that work takes on for the worker in his or her experience of it (Sandberg 2000). As Schön (1983) observes "when workers encounter their work, they frame and set the problem situations of the work through their experience of it. In other words, as workers frame their work, the attributes used in performing that work are not separate from their 
experience of it, but internally related to work through their way of framing the specific work situation” (Sandberg, 2000, p. 12).

Therefore, analogously to the worker, the researcher engages with research activities as his or her lived experience, and hence, research as well as the researcher become intrinsically related, one shaping the other as Escher's hands drawing one another. Hence, how we conduct research is intrinsically related with ourselves, our experience, and our community.

Therefore, our first point of departure lies in the idea of different conceptions of research. We derive these different conceptions based on prior work on engineers and knowledge workers and how they relate to their work. These ideas were originally developed by Sandberg (2000) in an article based on his $\mathrm{PhD}$ thesis and later developed and applied in the area of project organizing, both with regards to different conceptions of project management and different conceptions of competence among project workers (e.g. Partington et al. 2005; Borg \& Söderlund 2015). As being research the work of a researcher, it is reasonable to assume that researchers will conceptualise their research differently.

For these reasons, it becomes increasingly important that the researcher reflects about the role of the research in the production of scientific knowledge, as well as the role of the research in uncovering and producing managerial challenges and managerial implications of research, and so on. It also becomes important that the research engages in different kinds of knowledge interests and acknowledges the value of different kinds of knowledge to improve practice and society. This also points out the significance of linking knowledge with interest, which leads us to our second anchoring point: Habermas' work connecting knowledge and interests.

Habermas' work on knowledge interests is fundamental to the understanding of social science and different challenges facing knowledge production in social science. In Knowledge and Human Interest, Habermas purports to establish a critical social theory as a respectable and distinct form of knowledge to the then-dominant positivist philosophy of science and historicist hermeneutics, composing three different ways of knowing. Underlying his distinctions of three kinds of knowledge resides a typology of human interests, rooted in human existence as social and biological species. The three interests are expressed in particular types of scientific and scholarly inquiry. In that respect, the human interest of the researcher will determine to a great extent what kind of knowledge that research is likely to develop and along these lines also what research methods that might be most pertinent.

Technical interest refers to the anthropologically deep-seated interest to control and predict the natural environment. This interest motivates classic positivistic research inquiry, 'empiricalanalytic', to uncover law-lie regularities. It conceptualise science as instrumental and objective, in search of 'truth' which is understood as the verified fact through methodical experimentation, controlled observation, large sampling statistics, etc. The interpretive, or cultural-hermeneutic sciences are driven by the deep-seated practical interest to maintain or increase self and mutual understanding in life. Truth here is conceptualised as consensus or coherence - something is considered true if multiple people consider it to be true. Finally, the emancipatory interest has as core interest the wish to overcome dogmatism, compulsion, and domination. Habermas search for the epistemic and normative basis for such critique culminates his Theory of Communicative Action (Habermas 1985), which he developed later in his career. Table 1 provides a short overview of the human interests and kinds of knowledge presented in the work of Habermas. 


\begin{tabular}{|l|l|l|}
\hline Type of human interest & Kind of knowledge & $\begin{array}{l}\text { Research methods and } \\
\text { inquiries }\end{array}$ \\
\hline $\begin{array}{l}\text { Technical with a focus on } \\
\text { prediction and control }\end{array}$ & $\begin{array}{l}\text { Instrument (causal } \\
\text { explanation) }\end{array}$ & $\begin{array}{l}\text { Positivistic sciences } \\
\text { (empirical-analytic methods) }\end{array}$ \\
\hline $\begin{array}{l}\text { Practical with a focus on } \\
\text { interpretation and understanding }\end{array}$ & $\begin{array}{l}\text { Practical } \\
\text { (understanding) }\end{array}$ & $\begin{array}{l}\text { Interpretative research and } \\
\text { hermeneutic methods }\end{array}$ \\
\hline $\begin{array}{l}\text { Emancipatory with a focus on } \\
\text { criticism and pragmatism }\end{array}$ & Emancipation & Critical social sciences \\
\hline
\end{tabular}

Table 1: Overview of Habermas’ Three Ways of Knowing (based on Tinning 1992; Habermas 1987)

Many management disciplines have developed by transcending through all kinds of knowledge beginning with a strongly technical orientation, moving forward to a more interpretative/practical interests, and then developing a stronger emancipatory human interest. As for the latter, many argue that critical studies largely reside here. We believe critical studies are important for creating emancipation; however, there may be several other alternatives that could be worthwhile and do not necessarily subscribe to the guidelines of what most people refer to as critical studies. Emancipation, we believe, may be developed also through the introduction of new concepts, the presentation of cases that trigger new ideas and understandings, and critical analysis of current practices showing that there is something unusual and perhaps even 'wrong' with the way current practice operates.

\section{Framing directions for the future}

Based on the idea of different conceptions of research from Sandberg, and the three ways of knowing identified by Habermas, we develop a typology of different types of project research. We refer to those as type 1, type 2 and type 3, respectively. Table 2 offers an overview of the three identified types of project research.

The types should be seen as ideal types, and give only a rough picture of what currently goes on within project studies. Some research and researchers can cut across two types or attend to only a few of the aspects characterised below. However, as a conceptual framework, it helps to "organize empirical observations, but using a coherent and meaningful framework... to make sense of the field and understand its boundaries, major findings, and challenges” (Shapira, 2011, p. 1314).

\begin{tabular}{|l|l|l|l|}
\hline & \multicolumn{3}{|c|}{ Types of project research } \\
\hline $\begin{array}{l}\text { Framing } \\
\text { Attributes }\end{array}$ & Type 1 & Type 2 & Type 3 \\
\hline $\begin{array}{l}\text { Empirical } \\
\text { settings }\end{array}$ & $\begin{array}{l}\text { Any projects (projects } \\
\text { are seen as similar and } \\
\text { comparable) }\end{array}$ & $\begin{array}{l}\text { Specific types of } \\
\text { projects, and project } \\
\text { contexts }\end{array}$ & $\begin{array}{l}\text { 'Pink elephants' with } \\
\text { prominent ethical, } \\
\text { theoretical and/or practical } \\
\text { value/uniqueness }\end{array}$ \\
\hline
\end{tabular}




\begin{tabular}{|l|l|l|l|}
\hline $\begin{array}{l}\text { Theoretical } \\
\text { grounding }\end{array}$ & Project management & $\begin{array}{l}\text { General management } \\
\text { and organization theory }\end{array}$ & $\begin{array}{l}\text { Beyond management (e.g. } \\
\text { sociology, history, } \\
\text { philosophy, and physics) }\end{array}$ \\
\hline $\begin{array}{l}\text { Impact in } \\
\text { practice }\end{array}$ & $\begin{array}{l}\text { Mostly prescriptive } \\
\text { and normative, } \\
\text { attempting to 'solve' } \\
\text { the problem }\end{array}$ & $\begin{array}{l}\text { Actuality of project. } \\
\text { Mostly descriptive, with } \\
\text { implications to practice }\end{array}$ & $\begin{array}{l}\text { Legacy in contribution to } \\
\text { theory and/or practice } \\
\text { (impactful theoretical } \\
\text { development, preferably } \\
\text { rigor \& relevance) }\end{array}$ \\
\hline
\end{tabular}

Table 2: Three types of project research

Type 1 frames research in projects, for projects, and for project studies. It mostly focuses on project processes. Research tends to be paradigmatic, and refine classic and conventional topics in projects, adding some contributions to the field. This research has been analysed by many authors and given various names, including projects as plans-research (Packendorff, 1995), optimization school (Söderlund, 2011). It also includes broader success-oriented research trying to find the ultimate links between success criteria and success factors (Cooke-Davis 2002; Jugdev \& Müller 2005; Söderlund 2011). The research is still relevant, and important in terms of validation of our current knowledge.

However, this research is partly divorced from the real struggles in the 'reality' (realities) of projects, and/or 'big questions' and trends in general management and the world around us. This was one of the criticism raised by Winter et al (2006), calling research on the actuality of projects (Cicmil et al. 2006).

Type 2 research perceives projects as a unique opportunity to study and to contribute to particular theoretical questions in organization theory and general management. Projects are recognised as a temporary organization, and a context for theoretical development and empirical inquiry. An example of work in this area is what is oftentimes referred to as the Scandinavian School of Project Management (Sahlin-Andersson \& Söderholm 2002; Lundin \& Söderholm 1995). Its main focus is on understanding the characteristics and nature of projects as temporary organizations and its wider implications on creativity, learning and innovation. The work in this area has contributed to shifting project studies from being rather self-centric and not very well respected for developing relevant and theoretically rich research, and for receiving more recognition and attention from fellow scholars in allied management disciplines (Kwak \& Anbari 2009). IRNOP, which was launched in 1993 and had its first conference in 1994, has certainly played a very important role. The track at EURAM (and later in EGOS) on project organizing has also been important to drive this development (Söderlund \& Maylor 2012).

Type 2 is rather divorced and, often, in strong disagreement with type 1. Most typically, papers subscribing to this conceptualisation of project research begins with a departure and profound critique of type 1, arguing that type 1 research is too rationalistic, with far too little base on current practice, and with lack of social science framing.

Therefore, the Rethinking Network called for (social) theories and models as intellectual tools for analysing some aspect of the social world, in this case, projects. Echoing Fay (1990), the map (our concepts and theories) is not the terrain ('reality' of projects and project management), but 'relevant to' the terrain. In this regard, the theory will frame the social world in a specific way, and shed light 
into a particular aspect of project practice. Continuing on this analogy between map and theories, if the map would be identical to the terrain (same scale, showing all details), the map would be of little use. Therefore, a useful map makes some features more salient than others, for example, the topography, street names, wind flows, and country borders. Hence, we can readily appreciate that there is an infinite number of maps for any given terrain, as there are many theories that can be applied to any given situation; they will always be incomplete and imprecise, but, some are more useful than others. Project research following type 2 will have as its primary focus on the application of appropriate (i.e. insightful) theories to project contexts and middle range theorizing.

\section{Towards type 3 project research}

Type 3 project research builds on type 2 research and partly also on type 1 . It reconciles practical struggles with solid theories. Scholars conducting type 3 research are engaged in project practice and their contexts, and understand the 'realities' and challenges of the profession. However, similar to type 2, scholars subscribing to this idea of project research are aware of general academic conversations outside the project studies, but also engage in the ones within our community. They also recognise the potential for contributions to general theory, and are able to connect not only with general management and organisation theory conversations, but also areas outside management, most notably psychology, sociology and political science. In this regard, they will not only contribute with innovative ideas to the project studies but also to management and organisation theory.

They recognise and frame research around interesting, relevant and timely topics of concern in management but also to our society at large. They are the ones engaging with media, impacting companies and their management, but also policy by engaging with the general public and governmental institutions. Type three follows emancipatory knowledge interests, and help project practitioners to question work practices, and instigate them to change it. The focus is not only in deconstructing and problematizing, but also in contributing to the development of pragmatic (and contextualised) ways forwards. Ethical dilemmas and implications of choice of topics and empirical contexts are key concerns of scholars conducting type 3 research. They reflect on the examples and case studies they would like to use, searching for, for instance, more ethical projects, projects that engage with public, or, alternatively, hold a critical view on the potential negative effects of projects in local and global communities. Hence, type 3 research has a more active role in the development of our society and the impact of projects in society.

Finally, scholars working in accordance with the ideas of type 3 research recognise the importance of project studies as a community, and the need to harvest this community, in oppose to (only) joining other communities. Having said that, these scholars maintain strong linkages with external communities, publish in general management and organizational theory highly rated journals, bring inspirations from these fields, while also caring and contributing to the development of project research community, and acting as ambassadors of our community, whether explicitly or through their own outstanding research.

\section{Directions for future research}


We now turn to the application of the three research types to the five research directions proposed by the Rethinking Network back in 2006, which is summarised in Table 3 and discussed in the next sections..

\begin{tabular}{|c|c|c|c|}
\hline & \multicolumn{3}{|c|}{ Types of Project Research } \\
\hline & Type 1 & Type 2 & Type 3 \\
\hline \multicolumn{4}{|c|}{ Theory about practice } \\
\hline Direction 1 & $\begin{array}{l}\text { Lifecycle model of projects } \\
\text { and project management } \\
\text { (simple lifecycle assumed to } \\
\text { be the 'actual' practice) }\end{array}$ & $\begin{array}{l}\text { Theories of the } \\
\text { complexity of projects } \\
\text { and project management }\end{array}$ & Pluralism with a focus \\
\hline \multicolumn{4}{|c|}{ Theory for practice } \\
\hline Direction 2 & $\begin{array}{l}\text { Projects as instrumental } \\
\text { processes }\end{array}$ & $\begin{array}{l}\text { Projects as social } \\
\text { processes }\end{array}$ & $\begin{array}{l}\text { Social process with } \\
\text { technical core (which } \\
\text { does not fit all!) }\end{array}$ \\
\hline Direction 3 & $\begin{array}{l}\text { Product creation as the } \\
\text { prime focus }\end{array}$ & $\begin{array}{l}\text { Value creation as the } \\
\text { prime focus }\end{array}$ & Value for all \\
\hline Direction 4 & $\begin{array}{l}\text { Narrow conceptualisation of } \\
\text { projects }\end{array}$ & $\begin{array}{l}\text { Broader } \\
\text { conceptualisation of } \\
\text { projects }\end{array}$ & $\begin{array}{l}\text { Broader } \\
\text { conceptualisations } \\
\text { beyond projects }\end{array}$ \\
\hline \multicolumn{4}{|c|}{ Theory in practice } \\
\hline Direction 5 & $\begin{array}{l}\text { Practitioners as trained } \\
\text { technicians }\end{array}$ & $\begin{array}{l}\text { Practitioners as } \\
\text { reflective practitioners }\end{array}$ & $\begin{array}{l}\text { Practitioners as engaged } \\
\text { practitioners }\end{array}$ \\
\hline
\end{tabular}

Table 3: Directions for research in project studies

\section{Direction 1: Pluralism with a focus}

\section{The Rethinking Message}

The Rethinking Network concluded that "by far the clearest pattern to emerge from all the practitioner inputs to the Network is the sheer complexity of projects and programmes" (Winter et al., 2006, p. 641). They argued that "real projects and programmes are much more complex, unpredictable and multidimensional than the rational, deterministic model, which dominates the literature." (Winter et al, 2006, p. 644) Therefore, the authors called for a shift "from the simple lifecycle-based models of projects, as the dominant model of projects and project management" towards "the development of new models and theories which recognize and illuminate the complexity of projects and project management, at all levels.” (Winter et al., 2006, p. 642). The emphasis was placed on models and theories in plural, in other words, instead of searching for 'the general theory of project management', they suggest exploring (social) theories and models as intellectual tools for analysing some aspect of social world, in this case, projects. This plurality of 
models and theories, they argued, provides different lenses to 'see' projects, and hence challenges rational and deterministic assumptions which dominated most textbooks and conventional wisdom at the time.

\section{Ten years after}

Around the time of the special issue and in the years following it, the complexity of projects received much attention from project management scholars (and practitioners) (e.g. Geraldi et al. 2011; Cooke-Davies et al. 2008; Remington \& Pollack 2007; Bosch-Rekveldt et al. 2011). Early literature aimed at understanding the nature of complexity in projects ${ }^{1}$. The key contribution of this body of work was to shed light into the 'sheer complexity of projects', and unravel the multifaceted challenges of project work. Now research moved towards the shaping and managing of this complexity.

Apart from and in parallel to the explicit study of complexity, the community consolidated the call for shifting paradigms away from the rationalistic approaches characterising Type 1 research, which featured not only in the Rethinking Network, but prominently in the literature around the time (e.g. Crawford \& Pollack 2004; Buckle \& Thomas 2003; Koskela \& Howell 2002), and in particular after the Special Issue on Temporary Organizations in 1995. The articles build on the claim but also propose more specific alternative perspectives, for example, Rolfe proposes move of project management from a defence against organizational crises to a reflective and learning approach van der Hoorn and Whitty propose an alternative paradigm for projects based on Heidegger Being and Time, such as concept of Dasein, Others suggest breaking the dichotomy, or reconciling the paradox, for example, Bredillet suggests practice as a common ground for reconciling applied (which lends towards type 1) and basic research (lending towards type 2), Jacobsson et al (2015) building on Wittgenstein's concept of Familienähnlichkeit to reconcile opposing voices in project studies. These examples point to the movement towards Type 3 research.

Moreover, theory and theorising featured more prominently in articles in the field. Researchers not only focused on conversations within organization theory and management but have also been creative in drawing into theories from a helm of disciplines, including psychology, philosophy (e.g. Bredillet 2010; Rolfe 2011; van der Hoorn \& Whitty 2015), history (Lenfle \& Loch 2009; Söderlund \& Lenfle 2013), among others. The stronger focus on theories also gradually led to stronger theoretical contributions, awarding the presence of project scholars and project related topics in highly rated journals in management and organizational studies.

The diversity in theoretical grounding enriches the field, as anticipated by Winter et al, but it also causes fragmentation. For example, according to Scopus, Winter et al 2006 was cited around 200 times, half of it in project management journals, and the other half scattered in several journals, with not more than one citation per journal. Not only is studies in projects being cited but also published in a variety of fields (and communities). The spread of relevant work in projects across different journals also makes it hard to trace, acknowledge and build on important publications, findings and theoretical contributions.

Another source of fragmentation in the field is, ironically, its wide use and relevance to organizations and society. Projects have become extremely popular and the contemporary

\footnotetext{
${ }^{1}$ see Geraldi et al (2011) for a summary of literature and Cooke-Davies et al (2008) for an overview of complexity theory and its potential contributions to projects
} 
projectification is almost to be described as a pandemic (Lundin et al. 2015; Fough Jensen et al. n.d.). With the notion of projects being applied (by both academics and practitioners) to almost everything, in almost all type of contexts, does projects run the risk to become everything and nothing? If so, academics would consequently need to broaden their understanding of projects to accommodate such variety that what defines projects and integrate the field becomes nothing more than a task with a specific goal or focus, that will finish at some stage and with someone responsible to blame. Such empirical diffusion may hamper the development of a common language and threatens a genuine and constructive dialogue between project scholars and practitioners. While this can be a healthy development, with time, it could also segregate the project as academic field for good or bad. Thus, paradoxically, the wide applicability and popularity of projects could weaken the field, as we know it. On the bright side, it opens a bouquet of empirical contexts for project scholars, and allow the field to explore more theoretical questions that cut across the wide variety of project forms of organising.

\section{Ten years from now}

Research in project studies has become richer and more diverse, both theoretically and empirically. While we welcome such pluralism, we also contend that project studies, like many other subdisciplines of management and organization, is in risk of fragmentation and balkanization. In this regard, just as the theory of the firm would raise questions regarding why do firms exist, we, similarly, need to be able to answer the question why does the project studies exist? What integrates us? What are our boundaries? Following Knudsen (2003)'s call for balancing integration and pluralism in social science, and its developed in the field of project studies by Söderlund (2011), pluralism should be accompanied by integration efforts across the field. We therefore call for 'pluralism with a focus'.

We suggest two complementary types of integrative research to create awareness of diversity and potential connections between, on the one hand, the various theories and perspectives on projects, and, on the other, the diversity in empirical contexts. Several types of studies can support such integration. First, we subscribe to the idea of looking into research as conversations in the community, which is critical to advance a particular field of research (e.g. Huff 1999). Therefore, we call our peers to engage in the current debates, to answer to articles publically, to build on each other's work, to refer to earlier studies, to refer to other contributions, to criticize past research and so on. In parallel, works such as the 'Classics in Project Management' - focusing on past academic work (Söderlund \& Geraldi 2012) and 'Project History' (Söderlund \& Lenfle 2013) - focusing on empirical context - help us remind ourselves as a community of our history and legacy, and facilitate the development of a collective memory of the field, which can enable creative thinking (March 1991).

Second, various kinds of integrative theories or meta-theories can also play an important role in integrating the community. Applying Ritzer (1983)'s meta-theorising concepts to the field of project studies, integration across theoretical foundations can help to attain a deeper understanding of theory, to prelude theoretical development, and to create overarching frameworks to increase both the understanding of different perspectives as well as potential applicability to practice. Developing such integrative theories of projects, a few fundamental questions seem particularly important, namely why projects exist, why they differ, how they behave, what the value of management is, and what defines and determines the success and failure of projects (Söderlund 2004). 
Third, we should continue current efforts to develop typologies and taxonomies of projects. Typologies of empirical contexts would also help, and may lead into the development of subcommunities within the project research community, but may also help in the dialogue and crossfertilisation across different areas.

Finally, focus on specific practical challenges can provide us with a baseline (or focus) that refrain our work from relativism (Ritzer, 1983). In this regards, as Habermas had a focus on communication, and Marx on work, our focus can be on projects and specific empirical challenges in projects. In this regard, we align ourselves the Making Projects Critical initiative, but suggest that in parallel to a more elaborate critical studies of projects, there could be a stronger link between the de-construction and problematisation, and action in response to these issues. In this respect, scholars following this line of research could focus on a specific practical challenge, such as why do costs escalate? When and why top management support fail? How to obtain top management support to disputed projects? How to engage with public? How to learn within projects? How to learn between projects? What is the role of contexts in projects? How can systemic solutions at policy or institutional level counteract some of detrimental behaviours in projects? How to learn to be in projects and managing projects? What makes outstanding project managers? What constitutes project and project management success? To whom does project management success matter? Why, despite all criticism, is the iron triangle still the prevalent way of measuring project management success in practice? Is it fair? To whom? And what actually 'fair' means in this context?

\section{Direction 2: Social process with technical core}

\section{The Rethinking Message}

The Rethinking Network called for research on the "actuality of projects," i.e. research exploring what is really going on in the projects as opposed to what should be done were we in a rational and deterministic world (Cicmil et al. 2006). In a way, the call is similar to move in decision making back in the 1950s, from the prescriptive to descriptive models of decision making that explore how decisions are made in oppose to how we think they should be made. This major shift in decision making opens up for a completely new field of study, theories and insights such as those popularised by Kahneman and Tversky. If we are to follow the lead of decision making, moving from a prescriptive (type 1) to a descriptive (type 2) research, it is reasonable to expect that a stronger focus on the actuality of projects can yield theory development and, potentially, relevance to practice.

Within this broader plead, Winter et al (2006) calls specifically for a stronger focus on social processes in projects. The key insight is that projects are made by people and for people. This may sound self-evident to some, if not all, however, by in large, the social nature of project was insufficiently addressed by the mainstream research and guidance to practitioners. However, "practitioners ... explain events in terms of organisations and their interactions, seeing the adoption of projects and programme management, and the emergence of specific projects, as artefacts of the power relationship between different groups with competing interests.” (Winter et al, 2006, p. 644) Against this background, the author calls for further research on the "concepts and images, which focus on social interactions among people, illuminating: the flux of events and human action, and the framing of projects (and the profession) within an array of social agenda, practices, stakeholder relations, politics and power.” (p. 642) 


\section{Ten years after}

In the last decade, the actuality of projects has been increasingly recognized and studied. Likewise, social practices and project actors have received increased attention. Extend research explored areas including but is not limited to the role of relationships in the making of projects, for example, . the shaping of contracts and relational contracts continued to receive wide interest in practice. Walker and Walker (2015) provide an excellent overview of aspects and competences required for the development of relational contracts. The Heathrow T5 became a widely shared example of innovative forms of managing relationships between partners in the project, and developing an open culture. And, as the failing launch of T5 painfully confirmed, the case also points to the relevance of not including key stakeholders in such agreements (Brady et al. 2006). In a different context and theoretical grounding, the work of Manning and Sydow (Manning \& Sydow 2011; Manning 2010) draw on structuration theory and processual view to explore project networks as a particular form of organising work, and its social embeddedness. The work highlights, for instance, how relationships between project partners shape the projects, and can become path dependent. In parallel, concepts of Actor Network Theory (ANT) has been applied to understand the characteristics of networks in project contexts, key names in the area include, but are not limited to the works of Steen and of Pryke. Some studies (mostly outside the classic project studies) also are demonstrating the applicability of big data and data analyticsto project related issues, for example Parraguez et al (2015) study the information flow across different project phases, and Munch (2015) draws on social media and web corpus to identify the public perception of wind turbine developments. Blomquist et al (2010) launched an aligned stream of work answering explicitly for the call on the actuality of projects, and drawing on the work on strategy-as-practice, and the practice turn, suggest studies on project-as-practice. These are by far not comprehensive, but good examples of an answer to the call back in 2006 for a stronger focus on the actuality of projects.

\section{Ten years from now}

Research in the last decade advanced our understanding of the actuality and social practices in project. Having said that, there is still a long way to go. For example, studies on project governance have limited focus on the actual practices of governance, such as political processes, sense making and decisions (as criticised by e.g. van Marrewijk \& Smits 2015). Thus, further studies on social processes opening the black box of the actuality of projects is fundamental for the development of the field, and an area that should dominate most research.

Having said that, we need to be careful with a potentially dismissive attitude towards technologies, including project methods and tools. They are still fundamental for the understanding and development of projects, and they influence social processes. Indeed, as seminally demonstrated by Orlikowski (1992), technology shapes and is shaped by social practices. Many classic projects involve technology, such as capital projects, or IT, or new product development, and in so doing, they involve relevant technological decisions, and developments which are high risk, under high uncertainty due to the potential developments in technological landscape. Such decisions can be quite influential as they become irreversible and can lead to lock-ins and path dependencies. Finally, as the established research on boundary objects and thereof following emerging stream of work on the materiality of social practices defends, many of the tools and techniques create materiality that frames the development of the project. From this perspective, projects are processes that we create and influence, and technology (in its wide sense) plays an important role in that process, as it creates a basis for discussion and anchors negotiation of meaning (e.g. Yakura 2009; Yakura 2013; Ewenstein \& Whyte 2007; Geraldi \& Lechler 2012). 
Hence, technology is core to projects, and we therefore call for research on social processes with a technical core. The intricacies of social practices and technology in projects, which is, by no means, argued to be 'new', have the potential to dissolve some of the tensions between types 1 and 2 research. Such research also opens for possibilities in emancipation, if we consider technologies not only as obstacles but also as potential opportunity for change.

Future research can lead the way in understanding technological innovation in projects and for projects, and throughout the project development from idea to legacy. The role of social media in projects exemplify potential research avenues. For example, as projects can be seeing as a major recruiting exercise, where time and timing play a crucial role, how do technologies such as social networks shape the resourcing of projects? Do they dissolve some of the issues observed around path dependencies? Are we relating with more people, and do these relationships 'add value' for resourcing projects? Why?

Moreover, we observe an increase opposition to global projects (Henisz et al. 2012; Scott et al. 2011). Social media and big data present opportunities for project managers and sponsor to map discourses in the project, which can inform and enable engagement with wider range of stakeholders with reasonable effort. Can such analysis take place? Who would use it? Is it ethical? Does web corpus and social media reflect project perceptions hold in the 'offline world'? Similarly, research could explore how public perception of projects is expressed and 'created' through media (online and offline)? From a project management perspective, how to engage with public perception of projects? Can a project be 'safeguarded'? Should it? How to change the image of projects? For example, how to develop a narrative of project success? Flipping the coin, how can such technologies give voice to minorities, and allow them to 'fight against' large projects which they consider having limited value to society? Perhaps the very social movements against projects are shaped and executed as projects, and become an object of analysis of project studies.

In more generic terms, the intensification of use of internet and social media facilitates the work of truly global project teams, but also changed the way of engaging with stakeholders and enabled an increasing opposition (or support) of projects. In this regard, big data and data mining can impact practices in projects. Social media can also be used as means for integrating work, which is fundamental in managing projects (Davies \& Mackenzie 2014; Söderlund 2005). We scholars already draw on technologies such as Google Docs and DropBox to enable real-time coordination of work. IBM, for example, launched social media tool to enable exchange and projects through social media. BIM (Building Information Modelling) and 3D virtual design attempt to change the way partners design construction work, collectively. The initiatives still have limited success but they are steadily improving. How does technology impact the way we meet and interact in projects? How does it change the way we integrate work in projects? Such research touch upon the solid work on virtual teams, but goes beyond it.

Moreover, owning to the fundamental role time takes in projects, processual studies will be beneficial for the understanding of the behaviours in projects in general, as well as in relation to the role of technology in projects. The processual analysis of projects that has been presented so far provide modest understanding of what really goes on in projects, moving beyond many of the obvious things we already know, but instead offer thought-provoking and robust explanations that we have not seen before. In this regard, we need to develop a much more dynamic view on networks in projects, and join Manning and Sydow in their processual studies on project networks. 
In summary, we call for more studies on the actuality of projects, in particular processual studies, which can, among others, explore the role of technology as well as other global trends that change the way we do projects.

\section{Direction 3: Value for all}

The Rethinking Message

Reflecting conversations such as the critical engagement with notion of the 'iron triangle' as the dominant project success criteria, project marketing, project strategizing and servitisation, Winter et al calls for a shift from 'product creation' to 'value creation' and generally to a broader conception of what characterizes project success. They argue that "for many organisations, the main concern now is no longer the capital asset, system or facility, etc., but increasingly the challenge of linking business strategy to projects, maximising revenue generation, and managing delivery of benefits in relation to different stakeholder groups” (Winter et al, 2006, p. 644). Against this background, Winter et al (2006) called for the study of "concepts and frameworks which focus on: value creation as the prime focus of projects, programmes and portfolios” (p. 642). Value is likely to assume multiple meanings reflecting stakeholders' interests and how they change overtime. Therefore, the focus on value creation begs reflection on 'value to whom?', and how can we [researchers] assist practitioners to conceptualise the 'value' to be created from these programmes and projects? How can we account for the dynamic nature of value, when what is valued will change both during project and after project completion?

\section{Ten years after}

Looking at the development over the past decade, much literature has amended the conventional view on project success by introducing broader frameworks for understanding and shaping project success, a trend identified in the past (Jugdev \& Müller 2005). These broader approaches to project success highlight the importance to move beyond the triple constraints (e.g. Shenhar \& Dvir 2007). Beyond broadening the set of success criteria, we as a community embraced the need to better address the value for the client, including value in use, and impact in 'business success', along with the future oriented contributions, for instance with regards to new organizational capabilities, technical innovations, and organizational learning. Studies on project business and business models also enlighten our understanding of as forms of creating value, calling for business case of projects and applying strategy concepts to the shaping of projects (e.g. Artto et al. 2008). Maylor at al (2009) also point to the dynamic nature of performance, and show that constructs used to define expected quality are inherently different from those related to how quality is perceived (and experienced in the course of the project). The study suggests a potential challenge in our underlining assumptions of measurement of success against baselines. Developments in marketing and design have brought co-creation of value to mainstream in management, and had influence in project research and practice. For example, the Agile movement gained traction in the last decade, particularly since the agile manifesto in 2001, and includes co-creation of value and the participation of end users as part of the design project. This helped. Even the value of project management itself has been subject of intensive study, most notably by the research programme led by Thomas and Mullaly (2008) and funded by PMI.

Research also strengthened the relationship between success and failure in one hand, and human behaviour on the other. For example, Shepherd et al (2011) provide a refreshing perspective on the topic, and analyses the emotions of people leading with project failures, and how the 'get over it'. We also recognised the socially constructed nature of success and failure, and how they vary over 
time. In this regard, success becomes also narrative as oppose to the objective deviations from the initial baseline. For example, Kreiner's (2014) intriguing case studies point to examples of projects that would be defined as failures in the traditional sense (over budget and delayed), but were actually praised as successful by key stakeholders.

However, although the call raised the importance of value created by projects, extend research still provides scant attention to value beyond the dyad of project management (and consortium) and client/sponsor. In the last years, however, stakeholders and their different perspectives on value have gained increased attention. For example, Müller (2009) calls for a shift from shareholder to stakeholders view on value. Studies on the perspectives of different stakeholders on value are becoming more common (e.g. Davis 2014), and so are the myriad forms of encouraging convergence of multiple interests and views on value, such as the 'commons' investigated by Gil and Baldwin (2014), and the emerging work on public engagement in projects (Yu \& Leung 2015). In this line, further studies on projects in areas such as urban planning, major infrastructure and wind turbines can provide some interesting insights into the modes of collaboration with wide variety of stakeholders. Moreover, research on governance and governmentality, starting actually before the Rethinking call itself, has been pointing to such a pluralistic understanding of values (and interests). Also, studies on new forms of projects financing such as PPP (Public-Private-

Partnership) have an influence in our understanding of value creation and what is considered value. The research initiatives mentioned above are only a few examples of research, which place the view of the main actors in projects as part of the management task, and value creation process.

\section{Ten years from now}

As projects become increasingly integral to the nature of work (Lundin et al. 2015) and life (Fough Jensen et al. n.d.)in contemporary society, we need to continue and strengthen our work on project value and success. Doing 'good' projects, 'good' in projects, and good through projects must, thus, be heralded as overarching principles for shaping, managing, as well as researchingprojects.

Building on the contemporary understanding of projects as value creation process, and echoing Habermas emancipatory human interest, we call researchers to critically engage with the notions of success and value and join our aspiration and preoccupation with the creation of value, for all. We accept that this may be naïve and raises obvious incommensurability issues. But, such bold statement stresses the point we would like make, namely that projects, as a value creation process, is not 'value free', and hence future research needs also to engage with the ethics and social responsibility of projects - be it in the managing of projects, or in the legacy it creates.

An obvious stream of work following this line is the role of projects in sustainability and climate change. The London Olympics 2012 offers an interesting example in this regard, with its focus on legacy and Carbon footprint. The Special Issue edited by Huemann and Silvius on Managing Projects and Sustainability for the International Journal of Project Management is another key step in this direction. Another step is the work led by Morris and Teerikangas on the role of the management of projects, programs and portfolios in tackling the causes and consequences of climate change, and the role of us, project scholars, in engaging and acting on the problem (Morris et al, In Review).

Project research (and education) could for example, be more aware of the choice of cases and contexts, as well as raise questions such as: what is the social responsibility of projects? Why and how should projects engage in such concerns? How can the 'discipline' involved in managing 
projects, programs and portfolios help increase effectiveness and efficiency? What is the level of professionalization of sustainable development projects? How to improve it?

In parallel, future studies could draw on diplomacy and international relations and political sciences as well as psychology and sociology, to explore multiple facets of value, varying interests of stakeholders and their narratives, stories, metaphors to help practitioners to guide convergence of meaning, as well as to live and manage with high levels of ambiguity. Studying the actuality of governance, and approaches for opening governance can present interesting contexts for such inquiries. And, as we move towards more complex projects, and projects as a fundamental unit of economic and social action, inter-institutional projects and multiple institutional logics in projects play an ever more significant role, enhancing the importance of project governance. Moreover, decisions, behaviour in decisions as well as hard choices and ethics will be key. What are the ethical dilemmas of projects and project managers? How do these dilemmas differ across contexts and how do managers respond to such dilemmas in different settings? How may stakeholders of different kinds be involved in the shaping of projects? How may stakeholders of different kinds be involved in the implementation of projects? How can projects make better use of stakeholder resources? How to engage with the public and address their emotional reaction to projects? What governance models and practices will be important to shape the projects of the future? What governance models and practices will be important to implement tomorrow's projects? How can value be better created and how can value be better distributed among stakeholders?

\section{Direction 4: Broader conceptualisations beyond projects}

\section{The Rethinking Message}

Many projects start with a rather vague idea of an improved future state. During their implementation these ideas are transformed into more or less tangible outcomes. Managing projects involves the need to shape the 'messy' reality of projects, the expectations, the unrealism, the lies and the dreams and to make hard choices in face of high ambiguity and uncertainty. Many difficulties have to be addressed along the way: How to manage this shaping process? How to identify what is needed and valued, which stakeholders cannot fully articulate, nor are likely to be in agreement about? Against this background, the authors called for "new concepts and approaches which facilitate: broader and ongoing conceptualisations of projects as being multidisciplinary, having multiple purposes, not always pre-defined, but permeable, contestable and open to renegotiation throughout” (Winter et al, 2006, p. 642) and help project managers and other practitioners to conceptualise projects and programmes from different perspectives and 'focalise' action. In some respects, this call is similar to the call for plurality of theories (direction 1). The difference is the focus on the conceptualisation to guide practice and enable action, in oppose to guide research and develop theories. .

\section{Ten years after}

Several streams of research have been developed to better address these challenges. We will mention two examples. First, more research has looked into the front-end of project management and its current practices (Edkins et al. 2013). Following Morris (1997), the generation of projects (Söderlund, 2005) is considered a core element of successful projects, the decision-making processes are critical for understanding the future of a project, or if the project will have a future, or should have one (Winch 2013). The history of projects is essential to understand the future alternatives for specific projects. This has also paved the way for a larger interest in the path- 
dependency of projects (Manning \& Sydow 2011; Hellström et al. 2013) and generally the call for a historical perspective on projects (Scranton 2014; Söderlund \& Lenfle 2013). To some extent these attempts underline Hellgren and Stjernberg's (1995) seminal idea of a closer scrutiny of design is critical to understand how projects are implemented.

Second, research has argued for a broadening scope of project studies. This has,besides the longer view on its history, also developed in terms of its unit of observation. Most notably this has led to a stronger focus on program management (e.g. Martinsuo \& Lehtonen 2007; Pellegrinelli 2011; Maylor et al. 2006) and portfolio management (e.g. Unger et al. 2012; Martinsuo 2013; Killen et al. 2012; Petit 2012).

Third, we observe a stronger interest for locating project management in its social and institutional context. This has led researchers to underline the institutional elements of projects following the work by Engwall (2003). The work on Project Management Office (PMO) became quite fashionable in the years following the Rethinking Network. The research was often led or inspired by scholars such as Aubry and Hobbs (Pellegrinelli \& Garagna 2009; Aubry et al. 2007; Aubry et al. 2011), and made interesting contributions to theory as well as to practice. Today, PMOs are an essential part of most organization of project business. Studies have also advanced beyond the organisational level, and involved analyses of the global context of large projects (Scott et al. 2011), the national institutional context hosting projects (Sydow \& Staber 2002; Grabher 2002), and their related social networks (Manning \& Sydow 2011), within and beyond organizations directly engaged in projects (Morris \& Geraldi 2011; Morris et al. 2011) and the nature of so-called interinstitutional projects (Dille \& Söderlund 2011), and alternative approaches to guide their complex relationships (Walker \& Lloyd-Walker 2015; Bresnen 2010). The latter highlights the fact that projects often span institutional boundaries, regulatory frameworks (Klakegg et al. 2015), and organizational fields, which make it difficult for projects to uphold all-embracing legitimacy for what to produce, how to produce it, when to produce it, and who to involve (Brady et al. 2006). Problems that have been identified, but not yet fully understood, and where project scholars can make significant contribution to policy. This will bring us to our suggestions for future research direction.

\section{Ten years from now}

Projects shape our current society, from intensifying intermittent employment to inter-firm relationships. Moving forward, we can no longer investigate only the project, but project in context and contexts for projects (Morris \& Geraldi 2011; Morris et al. 2011). We therefore call for broader conceptualisations beyond projects, which examines projects in society, deeply rooted and embedded within time and space. Such embeddedness goes beyond the project itself and becomes context for projects. For example, it could build on work on PPPs'(Public Private Partnerships), project governance and multi-project governance, e.g. the OGC experience (Williams et al. 2010), and experiences in Australia (Walker \& Lloyd-Walker 2015). It could investigate the institutional context for projects beyond firm boundaries: how does such context impact projects, how does it enable collaboration, and create boundaries and structured to enable projects to succeed? How does such context look like? What can we learn and contribute to policy development at city, national and global levels? What makes some contexts more 'fruitful' than others? And fruitful to whom?

We have seen promising developments around the decision-making in and prior to large projects (e.g. Flyvbjerg et al. 2009; Winch 2013; see review in Geraldi \& Stingl 2016) We have also seen 
much research on project shaping (Cova \& Salle 2011; Kreiner \& Winch 2008). However, we still haven't seen good combinations, more insightful research on how decisions are made, what are the alternatives to lying? What are the implications to ethics? This certainly also points out the important role of understanding the legacy of projects, the path dependency of projects - how the history shapes the future of projects is certainly an important question for practitioners as well as researchers.

In addition, continuing on the institutional framing of projects - the growing size of projects needs to be analysed - in relation to firms, organisations, states, and government agencies. Projects are in some cases larger than some nation's Gross Domestic Product, and in some industries, projects are much larger than most firms participating in the project (Lundin et al. 2015). However, we still tend to believe that companies are more important than projects. This is indeed strange. Most firms would not exist without the project. From society's point of view, successful projects might be far more important than successful firms. Good projects for stakeholders are thus more critical for long-term development than profitable projects. Moreover, projects constitute alternative paths for economic and societal development, not only the building of infrastructure, which has been a common approach (e.g. the building of the Hoover Dams, or the first railway crossing North America in 1800s), but also encouraging project entrepreneurship. This assertion needs to be taken on board by researchers and developed in future research and empirical studies.

However, exploring the broader context of projects is not enough. We need to address the micro as well as the macro elements of projects. As argued by Evered and Louis (1981), we need to zoom in as well as zooming out, capture the big picture yet understand that the devil is in the details.

We also need to better understand the general use and proliferation of projects. To some extent and in some industries, we have seen heightening project hysteria - the project form has been over-used, almost abused. We use projects for all kinds of processes, tasks, etc. which has resulted in burdensome bureaucracy instead of organizational flexibility (Styhre 2006; Geraldi 2008). However, what are the underlying reasons for projects? What value does projects really produce? What are the costs of relying on projects as a form of problem-solving? In that respect, we also need to better understand the very foundation of projects - why do projects exist (Söderlund, 2004).

\section{Direction 5: Engaged practitioners}

\section{The Rethinking Message}

Last but not least, Winter et al explored the consequences of the above shifts to project managers and the required capabilities. They argued that "mainstream methods and techniques can be a useful source of guidance for certain aspects, but they provide no guidance on 'how' to navigate the complexity of projects in the ever-changing flux of events.” (p. 645) Navigating complexity requires qualities of reflective practitioners, which include "conceptualising projects from different perspectives, reading situations, problem setting, dealing with ambiguity, relating to wider issues, and political footwork." (p. 646) At the time of their writing, limited attention had been given to develop such skills and capabilities in the field of project management and against this background, the authors called for stronger focus on developing reflective capabilities, "enabling people to operate more effectively in the 'swampy lowlands' of projects and programmes.”

Indeed, one of the strongest points with the work by the Rethinking Network was to call for a different view on the collaboration between research and practice. The network argued that 
practitioners need to have a different view on what research is and how research can inform practice. They also argued that project managers must develop a more reflective mind-set to fully appreciate the emerging theories of project management: research does not always give the practitioner the answer and that researcher does not always give only one answer. Instead, in their view, research helps by giving the practitioner more options, new concepts, new ways of exploring reality.

\section{Ten years after}

In recent years, we have seen a strong development of project management education. Many project management education programs today have a very prominent role in business schools around the world (Söderlund \& Maylor 2012; Thomas \& Mengel 2008). More reflective training programs have also been developed and studies indicate that teaching today has embraced many of the core principles inherent in the idea of the reflective project manager, including special issue on project education (e.g. Thomas \& Mengel 2008; Berggren \& Söderlund 2008; Atkinson 2008) and beyond

Research has also documented the stronger focus on leadership capabilities and skills in project management. Examples include the development of the project manager profession inspired by Rethinking Network (Crawford, Morris, et al. 2006), authentic leadership (Lloyd-Walker \& Walker 2011), transformational leadership (Keegan \& Den Hartog 2004), contextualised view on leadership (Müller et al. 2012), relationship between program managers and how they shape the program (Partington et al. 2005). A heroic version of project leadership as a single person has also been criticised and distributed leadership has been observed and discussed (Buchanan et al. 2007; Crevani et al. 2007)

Research has also pointed out that project managers need to develop a more critical mindset towards the certain forms of project organizing and the negative consequences of project management (Hodgson \& Cicmil 2007). Moreover, project managers are often faced with difficult ethical dilemmas, such as the strong sense of reputation (Clegg \& Courpasson 2004), while fighting against the odds to deliver often unrealistic promises (Flyvbjerg et al. 2009). It is therefore not a surprise that work on ethics in projects gained increased attention, as exemplified by, for example, a special issue on ethics in project management in this journal (Müller 2013).

\section{Ten years from now}

Project managers have a challenging but also exciting job. They live from project to project, engaged in temporality while reflecting on legacy, identity and careers, and walking the fine line between creativity, professionalism and entrepreneurship under high time and political pressures. Navigating in the complex project landscapes is not an easy task, and the next ten years should continue efforts to educate and praise reflective practitioners.

However, we contend that this is required but not sufficient. As argued above, projects are embedded in their context, and not only depend on this context to survive, but also shape the context, for good or bad. As our society becomes increasingly dependent on projects, such legacy gains on relevance. Therefore, we call for an engaged practitioner, who are not only reflective, but also more aware of the legacy of their actions. Legacy takes many forms: the experience of individuals and groups, and project stakeholders in general, the project output and outcomes, as well as the process of getting there. Moreover, contemporary project managers (or teams) are role models for future generations. 
For example, CrossRail brought forth innovation agenda in projects, Heathrow T5 exemplifies differences in contracting. It is worth noting though that one does not need to manage a mega project to leave a legacy. For example, a construction project manager in southern Germany followed humanistic management approaches and changed practices, by, for example, to meet the demands of the clients and speed up the development of a construction site, it was required to work on construction site during winter. The project manager ensured basic conditions to make such work under cold temperatures more bearable. ${ }^{2}$.

Our research can take the role of uncovering such practices, disseminate work, show examples, and guide ethical choices. Research can directly or indirectly explore questions such as: how do project managers impact their context? Why do some do and others don't? Who can be role models for future generations of project manager? What are the barriers and enablers for a more engaged practice? How can our society (and our research and education) encourage and support such practices?

Accompanying the 'brave' project managers, is also the need for 'intelligent' client and policies for a project society. Such policies will help regulate complex questions, including from ethics to unemployment and retirement benefits. In this regard, project studies can inform policy about the realities of project managers and the required support.

\section{Direction 6: Reflective and Engaged Scholars}

Scholarship has been a central concept of the Rethinking Network. First, the work itself constitutes a moment of reflection and calls for fundamental changes in the research focus and methodologies in project studies. Second, the research directions were developed around the interplay between theory and practice. Third, the rethinking's research process itself was discussed in light of concepts of engaged scholarship (Winter, Smith, Cooke-Davies, et al. 2006). However, scholarship per se has not been spelled out as a research direction in its own right. We close the loop, and conclude the essay, by calling for a sixth research direction on the practice of theorising (or the practice of research), and, in doing so, we discuss the implications of research directions proposed above to project scholars and to the shaping of project studies.

Our starting point has been that research is a social practice, subject to complexities, uncertainties and social intricacies akin to those we study in projects (actually, great part of our work as scholars is organized through projects). Throughout this essay, we demonstrated that researchers are not only part of a field; they also shape it. Echoing Sandberg's (2000) interpretive approach to work-worker relationship, we argued that, there is a role for an interpretive approach to the relationship between research-researchers. Therefore, the meaning the research takes for researchers (project scholars) is fundamental to the development of project studies as an academic field, as well as its relationship with project, and society.

Therefore, this section reflects on the implications of the view argued in this essay, namely the active role of researchers towards project studies and implications of research to society, in general,

\footnotetext{
${ }^{2}$ Based on personal observation and conversation with the manager.
} 
and of the research directions proposed above to scholarship, in particular. We developed the discussion around three implications to project scholars and project studies.

First, strong focus on theoretical development should walk side-by-side with in in-depth understanding of the actuality of projects and engagement with project practice. Project studies theorise about project context and contribute to organization studies. Understanding the unique and defining characteristics of projects, as well as integrating perspectives on project studies constitute important starting points to find out in are that contribution may be. As argued in Direction 2, such understanding though needs to be embedded in the actuality of projects: projects are dynamic and we need dynamic theories to address them. To understand the long voyage of discovery in varied territories from technology to politics which is an essential part of project organizing - we need theories that address dynamics and evolution - the journey.

Moreover, following Direction 1, complex reality needs to be understood from several perspectives. It is critical to define and become aware of our own perspective not only for the development of one's own perspective but for the understanding and development of other perspectives. Pluralism can be enhanced as future studies more actively seize opportunities for theorising at the intersection, that is, borrowing, extending and transforming theories from other fields (Zahra \& Newey 2009). In this regard, metaphors can also be powerful, as they provide fresh insights (Tsoukas, 1991).

Finally, theories need also to address a set of fundamental questions concerning why projects exist, how they differ, how they behave, what the value of management in projects is, what differs success from failure (Söderlund, 2004). Theory development needs to be promoted to be able to contribute to the more general field of organization studies. Developing bolder and braver theories of projects seem to be critical for the development of the field.

Together these developments help us develop a richer repertoire and (common) language, which can open our eyes to new parts of the project 'realities'. The development of such (common) language is critical part of the job of the researcher, and fundamental for the development of project studies, and can contribute to a stronger contribution to organization studies.

Such developments though can risk project scholars and project studies to become isolated from what is most interesting in the field, namely the project context. Thus, in order to sustain the development of project studies, the practice of theorising should not be divorced from in-depth engagement with project practice. Therefore, in line with what has been suggested in Rethinking Network, project scholars and project studies would benefit from more than occasional consultancy work, but instead develop a continuous and strong engagement with practice, through e.g. ethnography studies, engaged scholarship, action research, interactive research (Eklund et al, 2008), mode 2 research (Gibbons et al. 1994).

Thus, theorising demands understanding of the practice and vice-versa. We therefore call for ambidextrous scholars, who are able to reconcile rigor and relevance. In other words, scholars engage with practice and understand its day-to-day challenges, and, is also capable to craft robust and insightful theories, that enable us not only to understand actuality of projects, but also question it, and theorise on it. We understand that balancing rigor and relevance is extremely difficult, as it requires two different mind-sets and comfortably navigate across different human interests, in Habermas' terms, potentially exposing scholars to difficult ethical and epistemological dilemmas. 
However, such development is fundamental to avoid the traps of either becoming only 'project management consultant' or only a 'publication machine'.

Second implication is the need for reflexivity in project studies. As Bourdieu argues, "in order to carry out the scientific project in the social sciences (and in our case, project studies), a further step is needed, one which the natural sciences do not require. To bring to light what is 'the hidden' par excellence, what escapes the gaze of science because it is hidden in the very gaze of the scientist" (2004, p.86).

In Cunliffe words, "reflexive scholars question the threads of philosophical and methodological certainty implicit in the goal of mainstream social science to provide an absolute view of the world. They suggest that all forms of inquiry are paradigmatically circumscribed (Burrell \& Morgan, 1979; Chia, 1996b), and therefore truth claims, assumptions about reality and the ways in which we generate accurate theories should be challenged to reveal the inherent instability of knowledge." (Cunliffe 2003, p.984) In this regard, reflexivity embodies the critical eye on theoretical and methodological apparatus and related research capabilities in the field. The relationship between knowledge and power is obviously eminent in the reflections. As argued by Hardy and Clegg, "all data are 'collaborative products' created in accordance with 'the practical procedures and background assumptions of the participating actors' (Knorr-Cetina, 1981). Thus, the relations between research subject, researcher and the protocols that comprise the research process both embody and obscure power. For this reason, it is important that theory strives for a high degree of reflexivity (Marcus, 1994) in accounting for its own theorizing, as well as whatever it is that it theorizes about." (Hardy \& Clegg 1997, p.S5) However, as argued by Bourdieu, "while there is value in self-awareness, sociological vigilance is not enough. Reflexivity takes on its full efficacy only when it is embodied in collectives which have so much incorporated it that they practise it as a reflex.” (2004, p.114).

We are fortunate in the sense that project studies values, and opens spaces for regular reflexivity and reflective scholarship, which welcome and embrace initiatives such as the Making Projects Critical, Rethinking Project Network and this special issue. In this line, we also call for sharp peer scrutiny in review processes, to increase quality of research. There is also a role for project scholars education in form of summer schools and pre-conference courses, particularly for PhD students and early career academics. Some already exist, but this could be extended.

Finally, if we have agency in developing the direction of research, and we know that knowledge is not neutral neither on its development nor on its consequences ${ }^{3}$ than, we, project scholars have the moral obligation to consider our research focus and potential implications to practice carefully. In this regard, project studies can investigate not only classic organization and management settings, but also engage with societal grand problems, as suggested in direction 4, see for example discussion of the role of project studies in tackling the causes and consequences of climate change (Morris et al, In Review). We find Habermas particularly inspiring, as he discerns different ways of knowing and defends the importance of emancipatory research, taking not only a critical stance but also a pragmatic one

\footnotetext{
${ }^{3}$ See e.g. Pfeffer and Salancik's resource dependence theory, for example in organisation/management domain (Pfeffer, 2005).
} 


\section{Conclusions}

We have also introduced the idea of referring to the field of project studies rather than project management research or project organizing research. There are several reasons why we believe project studies might be more accurate than other labels. First, it includes all kinds of management, organization, marketing, work-related challenges as it does not speak of either management, organization or anything like it. Second, it does not include a specific level of analysis but rather a general description of a theme that may include studies in the context of projects.

Our conceptual contribution has been to propose three distinct traditions in project studies, based on two theories: Sandberg's theory of competence at work, and Habermas' theory of knowledge and human interest. We claimed that all directions may prove important for the development of project studies - that work knowledge is needed, but equally that more emancipatory knowledge is also critical for the generation of a socially-concerned and critical stance of project organizing in society. We hope that our distinction can make us more aware of different kinds of approaches and researchers need, as well as the overall need for cross-fertilization and pluralism within the field, which calls for meeting places and dialogue across research traditions.

This essay has its problems and faults like most papers. We have focused more on generating new ideas than in systematically reviewing the field. Our purpose was however to give a narrative account of the status of the field and its related challenges. Our hope is that this account will lead project scholars as well as other scholars, to embark on more reflexive, social concerned, and emancipatory research in the field of projects. We need it and we need more research on projects. We have listed a few suggestions.

\section{References}

Artto, K. et al., 2009. Foundations of program management: A bibliometric view. , 27, pp.1-18.

Artto, K. et al., 2008. Project strategy: strategy types and their contents in innovation projects. International Journal of Managing Projects in Business, 1(1), pp.49-70.

Atkinson, R., 2008. Excellence in teaching and learning project management. International Journal of Project Management, 26(3), pp.221-222.

Aubry, M. et al., 2011. Pluralism in PMO performance: The case of a PMO dedicated to a major organizational transformation. Project Management Journal, 42(6), pp.60-77.

Aubry, M., Hobbs, B. \& Thuillier, D., 2007. A new framework for understanding organisational project management through the PMO. International Journal of Project Management, 25(4), pp.328-336.

Berger, P. \& Luckmann, T., 1966. The social construction of knowledge: A treatise in the sociology of knowledge, Soho, NY: Open Road Media.

Berggren, C. \& Söderlund, J., 2008. Rethinking project management education : Social twists and knowledge co-production. , 26(3), pp.286-296.

Biedenbach, T. \& Müller, R., 2011. Paradigms in project management research: examples from 15 
years of IRNOP conferences. International Journal of Managing Projects in Business, 4(1), pp.82-104.

Blomquist, T. et al., 2010. Project-as-practice: In search of project management research that matters. Project Management Journal, 41(1), pp.5-16.

Borg, E. \& Söderlund, J., 2015. Liminality competence: An interpretative study of mobile project workers’ conception of liminality at work. Management Learning, 46(3), pp.260-279.

Available at:

http://mlq.sagepub.com/content/early/2014/01/02/1350507613516247\nhttp://mlq.sagepub.co m/content/early/2014/01/02/1350507613516247.full.pdf.

Bosch-Rekveldt, M. et al., 2011. Grasping project complexity in large engineering projects: The TOE (Technical, Organizational and Environmental) framework. International Journal of Project Management, 29(6), pp.728-739. Available at: http://linkinghub.elsevier.com/retrieve/pii/S0263786310001122.

Bourdieu, P., 2004. Science of Science and Reflexivity, Cambridge: Polity Press.

Brady, T. et al., 2006. Learning to Manage Mega Projects: The case of BAA and Heathrow Terminal 5. , pp.1-12.

Bredillet, C.N., 2010. Blowing hot and cold on project management. Project Management Journal, 41(3), pp.4-20. Available at: http://doi.wiley.com/10.1002/pmj.20179.

Bresnen, M., 2010. Keeping it real? Constituting partnering through boundary objects. Construction Management and Economics, 28(6), pp.615-628.

Buchanan, D.A. et al., 2007. Nobody in charge: Distributed change agency in healthcare. Human Relations, 60(7), pp.1065-1090.

Buckle, P. \& Thomas, J., 2003. Deconstructing project management: A gender analysis of project management guidelines. International Journal of Project Management, 21(6), pp.433-441.

Cicmil, S. et al., 2006. Rethinking Project Management: Researching the actuality of projects. International Journal of Project Management, 24(8), pp.675-686.

Clegg, S. \& Courpasson, D., 2004. Political hybrids: Tocquevillean views on project organizations. Journal of Management Studies, 41(4), pp.525-547.

Cooke-Davies, T. et al., 2008. We're Not in Kansas Anymore, Toto: Mapping the Strange Landscape of Complexity Theory, and Its Relationship to Project Management. IEEE Engineering Management Review, 36(2), pp.5-21.

Cooke-Davis, T., 2002. The "real' Success factors on project. International Journal of Project Management, 20, p.5.

Cova, B. \& Salle, R., 2011. Shaping projects, building networks. In P. W. G. Morris, J. K. Pinto, \& J. Söderlund, eds. The Oxford Handbook of Project Management. Oxford, pp. 391-409.

Crawford, L., Morris, P., et al., 2006. Practitioner development: From trained technicians to reflective practitioners. International Journal of Project Management, 24(8), pp.722-733.

Crawford, L. \& Pollack, J., 2004. Hard and soft projects: A framework for analysis. International Journal of Project Management, 22(8), pp.645-653. Available at: 
http://linkinghub.elsevier.com/retrieve/pii/S026378630400047X [Accessed April 29, 2015].

Crawford, L., Pollack, J. \& England, D., 2006. Uncovering the trends in project management: Journal emphases over the last 10 years. International Journal of Project Management, 24(2), pp.175-184.

Crevani, L., Lindgren, M. \& Packendorff, J., 2007. Shared Leadership: A Postheroic Perspective on Leadership as a Collective Construction. International Journal of Leadership Studies, 3(1), pp.40-67.

Cunliffe, A.L., 2003. Reflexive Inquiry in Organizational Research: Questions and Possibilities. Human Relations, 56(8), pp.983-1003.

Davies, A. \& Mackenzie, I., 2014. Project complexity and systems integration: Constructing the London 2012 Olympics and Paralympics Games. International Journal of Project Management, 32(5), pp.773-790.

Davis, K., 2014. Different stakeholder groups and their perceptions of project success. International Journal of Project Management, 32(2), pp.189-201.

Dille, T. \& Söderlund, J., 2011. Managing inter-institutional projects: The significance of isochronism, timing norms and temporal misfits. International Journal of Project Management, 29(4), pp.480-490.

Edkins, A. et al., 2013. Exploring the front-end of project management. Engineering Project Organization Journal, 3(2), pp.71-85.

Engwall, M., 2003. No project is an island: Linking projects to history and context. Research Policy, 32(5), pp.789-808.

Evered, R. \& Reis, M., 1981. Alternative Perspectives in the Organizational Sciences: "Inquiry from the Inside” and "Inquiry from the Outside.” Academy of Management Review, 6(3), pp.385-395.

Ewenstein, B. \& Whyte, J.K., 2007. Visual representations as “artefacts of knowing.” Building Research \& Information, 35(1), pp.81-89.

Fay, B., 1990. Critical Realism? Journal for the Theory of Social Behaviour, 20(1), pp.33-41.

Flyvbjerg, B., Garbuio, M. \& Lovallo, D., 2009. Delusion and Deception in Large Infrastructure Projects: Two Models for Explaining and Preventing Executive Disaster. California Management Review, 51(2), pp.170-193.

Fough Jensen, A., Thuesen, C. \& Geraldi, J., The projectification of everything: projects as a human condition. Project Management Journal.

Geraldi, J. \& Lechler, T., 2012. Gantt charts revisited: A critical analysis of its roots and implications to the management of projects today. International Journal of Managing Projects in Business, 5(4), pp.578-594.

Geraldi, J., Maylor, H. \& Williams, T., 2011. Now, let’s make it really complex (complicated) A systematic review of the complexities of projects. International Journal of Operations \& Production Management, 31(9), pp.966-990.

Geraldi, J. \& Stingl, V., 2016. From Visions of Grandeur to Grand Failure: Alternative schools of 
descriptive decision theories to explain the Berlin Brandenburg Airport fiasco. In Proceeding of EURAM. Paris.

Geraldi, J. \& Teerikangas, S., 2009. From project management to managing by projects: Learning from the management of M\&As. In IRNOP - International Research Network on Organizing by Projects. Montreal.

Geraldi, J.G., 2008. The balance between order and chaos in multi-project firms: A conceptual model. International Journal of Project Management, 26(4), pp.348-356.

Gibbons, M. et al., 1994. The new production of knowledge: The dynamics of science and research in contemporary societies, Sage.

Gil, N.A. \& Baldwin, C.Y., 2014. Sharing Design Rights: A Commons Approach for Developing Infrastructure, Boston.

Grabher, G., 2002. Cool Projects, Boring Institutions: Temporary Collaboration in Social Context. Regional Studies, 36(3), pp.205-214.

Habermas, J., 1987. Knowledge and Human Interest, Cambridge: Polity Press.

Habermas, J., 1985. The theory of communicative action. Volume 2: Lifeworld and system: A critique of functionalist reason, Bacon Press.

Hanisch, B. \& Wald, A., 2012. A Bibliometric View on the Use of Contingency Theory in Project Management Research. Project Management Journal, 43(3), pp.4-23. Available at: http://doi.wiley.com/10.1002/pmj.21267.

Hardy, C. \& Clegg, S., 1997. Relativity without relativism: Reflexivity in post-paradigm organization studies. British Journal of Management, 8(2), pp.S5-S17.

Hellgren, B. \& Stjernberg, T., 1995. Design and implementation in major investments - A project network approach. Scandinavian Journal of Management, 11(4), pp.377-394.

Hellström, M. et al., 2013. Project governance and path creation in the early stages of Finnish nuclear power projects. International Journal of Project Management, 31(5), pp.712-723.

Henisz, W.J., Levitt, R.E. \& Scott, W.R., 2012. Toward a unified theory of project governance: economic, sociological and psychological supports for relational contracting. Engineering Project Organization Journal, 2(1-2), pp.37-55.

Hodgson, D. \& Cicmil, S., 2007. The politics of standards in modern management: Making "the project” a reality. Journal of Management Studies, 44(3), pp.431-450.

van der Hoorn, B. \& Whitty, S.J., 2015. A Heideggerian paradigm for project management: Breaking free of the disciplinary matrix and its Cartesian ontology. International Journal of Project Management, 33(4), pp.721-734. Available at: http://dx.doi.org/10.1016/j.ijproman.2014.09.007.

Huff, A.S., 1999. Writing for scholarly publication, Thousand Oaks: Sage.

Husserl, E., 1970. The crisis of European sciences and transcendental phenomenology: An introduction to phenomenological philosophy, Evanston: Northwestern University Press.

Jacobsson, M., Lundin, R.A. \& Söderholm, A., 2015. Researching Projects and Theorizing Families 
of Temporary Organizations. Project Management Journal, 46(5), pp.9-18.

Jugdev, K. \& Müller, R., 2005. A retrospective look at our evolving understanding of project success. Project Management Journal, 36(4), pp.19-31.

Keegan, A.E. \& Den Hartog, D.N., 2004. Transformational leadership in a project-based environment: a comparative study of the leadership styles of project managers and line managers. International Journal of Project Management, 22(8), pp.609-617.

Killen, C.P. et al., 2012. Advancing project and portfolio management research: Applying strategic management theories. International Journal of Project Management, 30(5), pp.525-538.

Klakegg, O.J., Williams, T. \& Shiferaw, A.T., 2015. Taming the "trolls”: Major public projects in the making. International Journal of Project Management, In Press.

Koskela, L. \& Howell, G., 2002. The underlying theory of project management is obsolete 1. In PMI Research Conference, June, Seattle. pp. 1-16.

Kreiner, K., 2014. Restoring Project Success as Phenomenon, Copenhagen.

Kreiner, K. \& Winch, G.M., 2008. Future Perfect Strategy: The Role of Imagination and the Risk of Empty Horizons. Managing the Construction of Buildings, CLiBYG Conference, Copenhagen, p.35.

Kwak, Y.H. \& Anbari, F.T., 2009. Analyzing project management research: Perspectives from top management journals. International Journal of Project Management, 27(5), pp.435-446.

Lenfle, S. \& Loch, C.H., 2009. Lost Roots : How Project Management Settled on the Phased Approach (and compromised its ability to lead change in modern enterprises). Ecole Polytechnique website, pp.1-29. Available at: http://papers.ssrn.com/sol3/Delivery.cfm?abstractid=1501176/nhttp://scholar.google.com.prox y.lib.pdx.edu/scholar?q=related:13C-

nC34NpEJ:scholar.google.com/\&hl=en\&as_sdt=0,38\nhttp://papers.ssrn.com.proxy.lib.pdx.ed u/sol3/papers.cfm?abstract_id=1501176.

Lloyd-Walker, B. \& Walker, D., 2011. Authentic leadership for 21st century project delivery. International Journal of Project Management, 29(4), pp.383-395.

Lundin, R.A. et al., 2015. Managing and Working in Project Society, Cambridge: Cambridge University Press.

Lundin, R.A. \& Söderholm, A., 1995. A theory of the temporary organization. Scandinavian Journal of Management, 11(4), pp.437-455.

Manning, S., 2010. The strategic formation of project networks: A relational practice perspective. Human Relations, 63(4), pp.551-573.

Manning, S. \& Sydow, J., 2011. Projects, paths, and practices: Sustaining and leveraging projectbased relationships. Industrial and Corporate Change, 20(5), pp.1369-1402.

March, J.G., 1991. Exploration and Exploitation in Organizational Learning. Organisation Science, 2(1), pp.71-87.

van Marrewijk, A. \& Smits, K., 2015. Cultural practices of governance in the Panama Canal Expansion Megaproject. International Journal of Project Management. 
Martinsuo, M., 2013. Project portfolio management in practice and in context. International Journal of Project Management, 31(6), pp.794-803.

Martinsuo, M. \& Lehtonen, P., 2007. Program and its initiation in practice: Development program initiation in a public consortium. International Journal of Project Management, 25(4), pp.337345.

Maylor, H. et al., 2006. From projectification to programmification. International Journal of Project Management, 24(8), pp.663-674.

Maylor, H. et al., 2009. Mind the gap: temporal disconnects in the provision of complex service offerings. In 16th Annual International EurOMA Conference, Göteborg, Sweden.

Merton, R.K., 1973. The sociology of science: Theoretical and empirical investigations, Chicago: University of Chicago Press.

Morris, P.W.G., 1997. The management of projects, Thomas Telford.

Morris, P.W.G. \& Geraldi, J., 2011. Managing the Institutional Context. Project Management Journal, 42(6), pp.20-32.

Morris, P.W.G., Pinto, J.K. \& Söderlund, J., 2011. Introduction: Towards the Third Wave of Project Management. In The Oxford Handbook of Project Management. pp. 1-12.

Müller, R., 2009. Project Governance, Surrey: Gower.

Müller, R., 2013. Special issue on ethics in project management. International Journal of Managing Projects in Business, 6(2).

Müller, R., Geraldi, J. \& Turner, J.R., 2012. Relationships between leadership and success in different types of project complexities. IEEE Transactions on Engineering Management, 59(1), pp.77-90.

Orlikowski, W.J., 1992. The Duality of Technology : Rethinking the Concept of Technology in Organizations. Organization Science, 3(3), pp.398-427.

Parraguez, P., Eppinger, S.D. \& Maier, A.M., 2015. Information Flow Through Stages of Complex Engineering Design Projects: A Dynamic Network Analysis Approach. IEEE Transactions on Engineering Management, 62(4), pp.604-617. Available at: http://ieeexplore.ieee.org/lpdocs/epic03/wrapper.htm?arnumber=7298074.

Partington, D., Pellegrinelli, S. \& Young, M., 2005. Attributes and levels of programme management competence: An interpretive study. International Journal of Project Management, 23(2), pp.87-95.

Pellegrinelli, S., 2011. What's in a name: Project or programme? International Journal of Project Management, 29(2), pp.232-240.

Pellegrinelli, S. \& Garagna, L., 2009. Towards a conceptualisation of PMOs as agents and subjects of change and renewal. International Journal of Project Management, 27(7), pp.649-656.

Petit, Y., 2012. Project portfolios in dynamic environments: Organizing for uncertainty. International Journal of Project Management, 30(5), pp.539-553.

Pollack, J., 2007. The changing paradigms of project management. International Journal of Project 
Management, 25(3), pp.266-274.

Pollack, J. \& Adler, D., 2014. Emergent trends and passing fads in project management research: A scientometric analysis of changes in the field. International Journal of Project Management, 33(1), pp.236-248. Available at:

http://www.sciencedirect.com/science/article/pii/S0263786314000787.

Remington, K. \& Pollack, J., 2007. Tools for complex projects, Surrey: Gower.

Ritzer, G., 1983. Sociological theory, New York: McGraw-Hill Education.

Rolfe, B., 2011. Reflect or Defend? Project Management as an Existential Response to Organisational Crisis. Philosophy of Management, 10(3), pp.59-77.

Sahlin-Andersson, K. \& Söderholm, A., 2002. Beyond project management: New perspectives on the temporary-permanent dilemma, Malmö: Liber.

Sandberg, J., 2000. Understanding human competence at work: An interpretative approach. Academy of Management Journal, 43(1), pp.9-25.

Schütz, A., 1945. On Multiple Realities. Philosophy and Phenomenological Research, 5(4), pp.533-576.

Schön, D.A., 1983. The reflective practitioner: How professionals think in action, Basic Books.

Scott, W.R., Levitt, R.E. \& Orr, R.J., 2011. Global Projects: Institutional and Political Challenges, Cambridge: Cambridge University Press.

Scranton, P., 2014. Projects as a focus for historical analysis: surveying the landscape. History and Technology, 30(4), pp.354-373.

Shenhar, A.J. \& Dvir, D., 2007. Reinventing project management: the diamond approach to successful growth and innovation, Boston: Harvard Business Review Press.

Shepherd, D. a., Patzelt, H. \& Wolfe, M., 2011. Moving forward from project failure: Negative emotions, affective commitment, and learning from the experience. Academy of Management Journal, 54(6), pp.1229-1259.

Smyth, H.J. \& Morris, P.W.G., 2007. An epistemological evaluation of research into projects and their management: Methodological issues. International Journal of Project Management, 25(4), pp.423-436.

Styhre, A., 2006. The bureaucratization of the project manager function: The case of the construction industry. International Journal of Project Management, 24(3), pp.271-276.

Svejvig, P., 2012. Rethinking Project Management in Denmark. In Project Management Multiplicity: Current trends. Frederiksberg: Samfundslitteratur, pp. 39-58.

Svejvig, P. \& Andersen, P., 2015. Rethinking project management: A structured literature review with a critical look at the brave new world. International Journal of Project Management, 33(2), pp.278-290.

Sydow, J. \& Staber, U., 2002. The Institutional Embeddedness of Project Networks: The Case of Content Production in German Television. Regional Studies, 36(3), pp.215-227.

Söderlund, J., 2004. Building theories of project management: Past research, questions for the 
future. International Journal of Project Management, 22(3), pp.183-191.

Söderlund, J., 2011. Pluralism in Project Management: Navigating the Crossroads of Specialization and Fragmentation. International Journal of Management Reviews, 13(2), pp.153-176.

Söderlund, J., 2005. What project management really is about: alternative perspectives on the role and practice of project management. International Journal of Technology Management, 32(3/4), pp.371-387.

Söderlund, J. \& Geraldi, J., 2012. Classics in project management: revisiting the past, creating the future. International Journal of Managing ..., 5(4), pp.559-577.

Söderlund, J. \& Lenfle, S., 2013. Making project history: Revisiting the past, creating the future. International Journal of Project Management, 31(5), pp.653-662.

Söderlund, J. \& Maylor, H., 2012. Project management scholarship: Relevance, impact and five integrative challenges for business and management schools. International Journal of Project Management, 30(6), pp.686-696.

Thomas, J. \& Mengel, T., 2008. Preparing project managers to deal with complexity - Advanced project management education. International Journal of Project Management, 26(3), pp.304315.

Thomas, J. \& Mullaly, M., 2008. Researching the value of project management, Project Management Institute.

Tinning, R., 1992. Reading Action Research: Notes on Knowledge and Human Interests. Quest, 44(1), pp.1-14.

Unger, B.N. et al., 2012. Enforcing strategic fit of project portfolios by project termination: An empirical study on senior management involvement. International Journal of Project Management, 30(6), pp.675-685.

Walker, D.H.T. \& Lloyd-Walker, B., 2015. Collaborative Project Procurement Arrangements, Project Management Institute.

Williams, T. et al., 2010. An investigation of governance frameworks for public projects in Norway and the UK. International Journal of Project Management, 28(1), pp.40-50.

Williams, T., 2005. Assessing and moving on from the dominant project management discourse in the light of project overruns. IEEE Transactions on Engineering Management, 52(4), pp.497508.

Winch, G.M., 2013. Escalation in major projects: Lessons from the Channel Fixed Link. International Journal of Project Management, 31(5), pp.724-734.

Winter, M., Smith, C., Morris, P., et al., 2006. Directions for future research in project management: The main findings of a UK government-funded research network. International Journal of Project Management, 24(8), pp.638-649.

Winter, M., Smith, C., Cooke-Davies, T., et al., 2006. The importance of “process” in Rethinking Project Management: The story of a $\{\mathrm{UK}\}$ Government-funded research network. International Journal of Project Management, 24(8), pp.650-662.

Yakura, E.K., 2009. Charting Time: Timelines as Tempral Boundary Objects. Academy, The 
Journal, Management, 45(5), pp.956-970.

Yakura, E.K., 2013. Visualizing an information technology project: The role of powerpoint presentations over time. Information and Organization, 23(4), pp.258-276. Available at: http://dx.doi.org/10.1016/j.infoandorg.2013.07.003.

Yu, J. \& Leung, M., 2015. Exploring factors of preparing public engagement for large-scale development projects via a focus group study. International Journal of Project Management, 33(5), pp.1124-1135.

Zahra, S.A. \& Newey, L.R., 2009. Maximizing the impact of organization science: Theory-building at the intersection of disciplines and/or fields. Journal of Management Studies, 46(6), pp.1059-1075. 